\title{
Demokracja bezpośrednia a wprowadzenie praw wyborczych dla kobiet - przykład Szwajcarii
}

K onfederacja Szwajcarska (Confoederatio Helvetica, Schweiz, Schweiprzyjętych tam rozwiązań - perłą demokracji - zajmuje szczególne miejsce na tle innych państw współczesnego świata. Ta wyjątkowa pozycja wynika między innymi z faktu, iż Szwajcaria jest państwem związkowym ulokowanym w środku Europy. Można rzec, iż historycznie, szwajcarska tożsamość została osadzona na wierze w federalizm, w wizję neutralności oraz w demokrację bezpośrednią.

Federacja szwajcarska powstawała inaczej niż większość państw związkowych w Europie - od dołu do góry. Od samorządnych górskich gmin, poprzez kantony, do związku kantonów, które łącząc się stopniowo ze sobą, utworzyły państwo. Nie bez znaczenia jest zatem fakt, iż Szwajcaria to państwo różnorodne nie tylko pod względem geograficznym, ale i narodowo-społecznym. Po pierwsze, jest państwem składającym się z trzech odmiennych regionów geograficznych: Alp, gęsto zaludnionej Wyżyny Szwajcarskiej (Plateau Suisse), na której znajdują się prawie wszystkie (poza Genewą i Bazyleą) największe miasta: Berno, Zurych, Lozanna, Lucerna i Winterthur, a także pasma górskiego Jury, rozciagającego się wzdłuż granicy z Francją, od kantonu o tej samej nazwie na północnym wschodzie po kantony Neuchâtel i Vaud na południowym zachodzie.

Po drugie, Szwajcaria podzielona jest na 26 różnych kantonów (w praktyce 23 kantony, z których 3 zostały podzielone na 2 półkantony), które z kolei dzielą się na łącznie około 2600 gmin. Trzecim elementem różnicującym Szwajcarię jest język. W tym państwie istnieją cztery strefy językowe. Większość Szwajcarów mieszka w strefie niemieckojęzycznej, która obejmuje 19 z 26 kantonów Szwajcarii - około $64 \%$ społeczeństwa posługuje się językiem niemieckim. W języku francuskim mówią mieszkańcy 4 kantonów: Genewa, Vaud, Neuchâtel i Jura. Ponadto w części 3 kantonów (Berno, Fryburg, Valais) mówi się po 


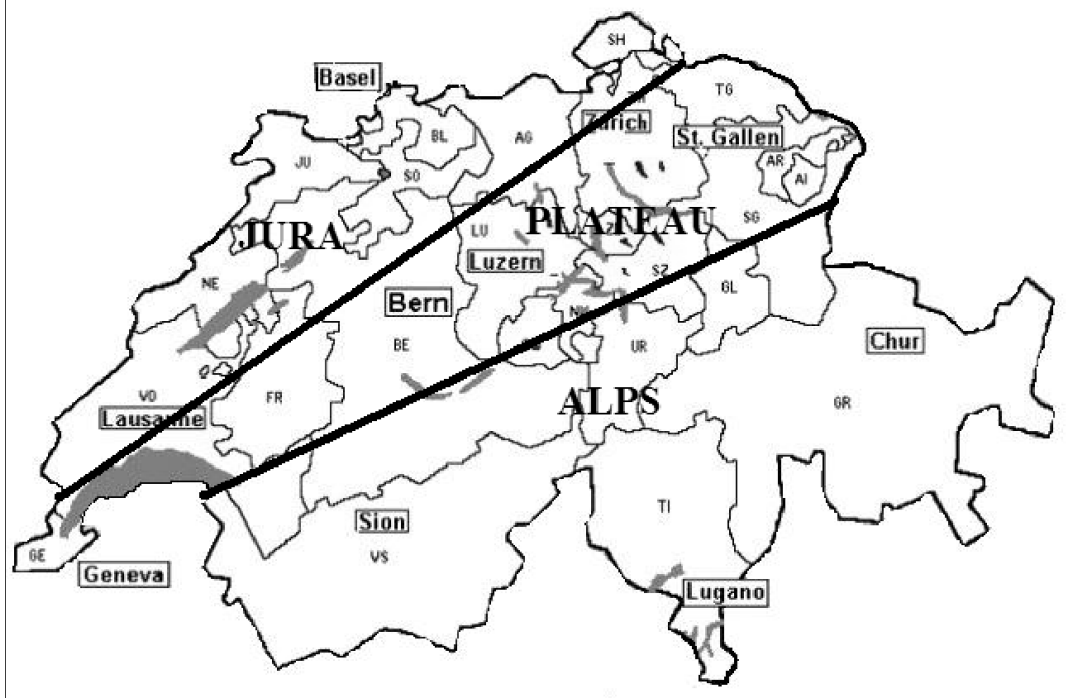

Mapa 1. Szwajcaria - podział na regiony i na kantony

Źródlo: Information about Switzerland, http://www.about.ch/cantons/index.html, 15.06.2012.

niemiecku i francusku. Łącznie około 20\% mieszkańców Szwajcarii posługuje się językiem francuskim. W języku włoskim mówią mieszkańcy kantonu Ticino (na południu Alp) oraz 4 południowych dolin kantonu Gryzonia - łącznie około 6,5\% populacji. Warto przypomnieć, że kanton ten jest regionem wielojęzycznym. Tu mówi się generalnie po niemiecku, ale także po włosku (w 4 południowych dolinach) oraz w języku retoromańskim (w kilku regionach tego kantonu). Tym ostatnim językiem posługuje się łącznie około 0,5\% mieszkańców całego państwa.

Kolejnym elementem różnicującym Szwajcarię jest religia, która również w istotny sposób wpływa na społeczeństwo. Szwajcaria to kraj, w którym dominują dwa wyznania: katolickie (około $42 \%$ populacji) i protestanckie (około $35 \%$ populacji). Niecałe $2 \%$ ludności to wyznawcy prawosławia. Prócz chrześcijan wyróżnia się również przedstawicieli innych religii: islamu (4,3\% mieszkańców), judaizmu, buddyzmu, czy hinduizmu, a także innych religii lub sekt (łącznie około $2 \%$ mieszkańców).

Konfederacja Szwajcarska znana jest również z tego, że od kongresu wiedeńskiego z 1815 r. jest państwem neutralnym, a o przywiązaniu do tego statusu świadczy m.in. fakt, iż państwo to nie jest członkiem Unii 
Europejskiej, a do Organizacji Narodów Zjednoczonych wstąpiło dopiero we wrześniu 2002 r. po przegłosowaniu tej decyzji w referendum minimalną większością 52\% głosów.

Kluczowym jednak elementem wyróżniającym to niewielkie europejskie państwo jest przyjęcie rozwiązań charakterystycznych dla bezpośredniego sprawowania władzy. Na każdym szczeblu podziału administracyjnego państwa wykorzystywane są instytucje demokracji bezpośredniej, które służą uprawnionym wyborcom do podejmowania wielu decyzji o różnym stopniu ważności. I tak na poziomie federacji Szwajcarzy mogą głosować w obligatoryjnym referendum konstytucyjnym, w fakultatywnym referendum ustawodawczym (do przeprowadzenia takiego głosowania wymaga się zebrania 50 tys. podpisów lub wniosku ośmiu kantonów) czy w referendum, będącym wynikiem inicjatywy ludowej (do przeprowadzenia takiego głosowania wymaga się zebrania 100 tys. podpisów) ${ }^{1}$. W kantonach oprócz obu typów referendów oraz inicjatywy funkcjonuje instytucja zgromadzenia ludowego - Landsgemeinde (wyłącznie w dwu kantonach - Glarus i Appenzell Innerrhoden $)^{2}$. Podobnie jest w gminach - tam prócz referendów i inicjatywy mamy również do czynienia z lokalnymi zgromadzeniami ludowymi, z tym jednak zastrzeżeniem, iż niemal w $80 \%$ gmin ta instytucja nadal funkcjonuje ${ }^{3}$.

Szwajcaria to bez watpienia kraj, który przez wieki wypracował sobie niepowtarzalną i nieistniejącą nigdzie indziej państwowość, która

1 W. Linder, Blaski i cienie demokracji bezpośredniej, w: Demokracja bezpośrednia. Szwajcarska demokracja modelem dla XXI wieku?, red. K. Koźbiał, Warszawa 2011, s. 15.

2 Instytucja Landsgemeinde ze względów praktycznych została zniesiona we wszystkich kantonach z wyjątkiem dwóch wymienionych powyżej. Tam nadal corocznie odbywają się zgromadzenia ludowe: w Glarus - w pierwszą niedzielę maja, a w Appenzell Innerrhoden - w ostatnią niedzielę kwietnia. We wszystkich pozostałych kantonach funkcjonowanie Landsgemeinde zostało zaniechane, ponieważ niepraktyczne było funkcjonowanie zgromadzenia z ogromną liczbą obywateli uprawnionych do brania w nim udziału. Dodatkową przyczyną zlikwidowania Landsgemeinde była krytyka tego, że ta formuła nie zapewnia jednej z fundamentalnych zasad demokracji - tajności głosowania.

3 Warto przy tym zaznaczyć, iż większość gmin szwajcarskich liczy mniej niż tysiąc mieszkańców - stąd instytucja Landsgemeinde sprawdza się w tych społecznościach. W większych gminach frekwencja na zgromadzeniach ludowych jest bardzo niska, co też wpływa na odchodzenie wielu gmin od tej formy sprawowania władzy. Szerzej: A. Ladner, Size and direct democracy at the local level: the case of Switzerland, ,Environment and Planning. Government and Policy” 2000, vol. 20, s. 813-828. 
funkcjonuje w specyficznych warunkach geograficznych, społecznych i politycznych, w obrębie oddziaływania kształtowanej przez stulecia tradycji sprawowania bezpośrednich form władzy. Wydaje się jednak, iż te narzędzia demokracji bezpośredniej hamują czasami zmiany, które wydają się niezwykle istotne z punktu widzenia rozwoju współczesnej państwowości i demokracji. Tak było z nadaniem praw wyborczych kobietom. Mimo iż wiele państw Europy i świata przyznało kobietom prawa głosowania i kandydowania w wyborach w pierwszych 20-30 latach $\mathrm{XX}$ wieku, to w Szwajcarii zmiana ta wymagała o wiele dłuższego czasu.

Warto przypomnieć, iż w Nowej Zelandii, kobiety uzyskały czynne prawo wyborcze już w roku 1893, natomiast prawo do kandydowania - w 1919 r. W Australii prawo wyborcze dla kobiet wprowadzono w 1902 r., cztery lata później prawa wyborcze uzyskały Finki, a Rosjanki i Polki, a także obywatelki Austrii i Niemiec w roku 1918. W Stanach Zjednoczonych kobietom przyznano prawa wyborcze w 1920 r. Ponad dwadzieścia lat później - w 1944 i 1945 r. - prawo do głosowania i do kandydowania uzyskały odpowiednio Francuski i Włoszki. Szwajcarzy na szczeblu federacji przyznali prawa wyborcze kobietom dopiero w 1971 r., co w przypadku państwa, które przez wielu nazywane jest perłą demokracji - może być dość dużym zaskoczeniem. Jeszcze większym zaskoczeniem może być zapewne fakt, iż jako ostatnie - mieszkanki kantonu Appenzell Innerrhoden uzyskały możliwość uczestniczenia w życiu politycznym kantonu dopiero w 1990 r. Ta różnica czasowa jest wynikiem faktu, iż nowo-przyjęte przepisy odnoszące się do federacji, nie obowiązują automatycznie w poszczególnych kantonach, które wprowadzają nowe przepisy w dogodnym dla siebie terminie. Dlatego prawa wyborcze były już przyznane kobietom w niektórych kantonach zanim uczyniono to $\mathrm{w}$ federacji, natomiast $\mathrm{w}$ innych kantonach przyjęcie praw wyborczych dla kobiet odbyło się po referendum w 1971 r.

\section{Droga kobiet do uzyskania praw wyborczych. Dwa referenda w tej samej sprawie}

Analizując historię uzyskania przez obywatelki Szwajcarii praw wyborczych, można stwierdzić iż była ona stosunkowo długa. Za jej początek uznać można lata 60-te XIX stulecia, zaś jej zwieńczeniem - jak zostało wspomniane powyżej - był rok $1971 \mathrm{w}$ przypadku federacji oraz rok 1990 w przypadku kantonów. 
Pierwsze ogólnokrajowe stowarzyszenie, które walczyło o prawa obywatelskie oraz możliwość studiowania dla kobiet zostało założone w 1868 r. Pierwszy wysunięty w 1886 r. przez kobiety postulat przyznania im praw wyborczych w kantonie Zurych okazał się nieskuteczny ${ }^{4}$. Kilka lat później - w 1993 r. - Szwajcarskie Stowarzyszenie Kobiet Pracujących $^{5}$ bezowocnie domagało się prawa do głosowania w wyborach i referendach państwowych. W 1904 r. utworzona w 1888 r. Socjaldemokratyczna Partia Szwajcarii (Sozialdemokratische Partei der Schweiz, SP) wprowadziła postulat przyznania kobietom praw wyborczych do swojego programu ${ }^{6}$. Pięć lat później kilka regionalnych organizacji utworzyło Szwajcarskie Stowarzyszenie na Rzecz Prawa Głosu dla Kobiet, które domagało się równych praw dla kobiet we wszystkich dziedzinach życia społecznego i politycznego. W 1912 r. szwajcarscy socjaldemokraci wobec sprzeciwu partii liberalnej i konserwatystów nie zdołali przeforsować praw wyborczych dla kobiet w kantonie Sankt Gallen. Podobne inicjatywy okazały się bezowocne w kantonach: Bazylea, Berno, Genewa, Neuchâtel, Zurych i Vaud.

Okres po pierwszej wojnie światowej był dość charakterystyczny w Szwajcarii - podczas gdy w wielu państwach wprowadzano prawa wyborcze dla kobiet, w federacji kolejne projekty były regularnie odrzucane w referendach kantonalnych ${ }^{7}$. W związku $\mathrm{z}$ tym, że proponowane rozwiązania korzystne dla kobiet nie były wdrażane na poziomie kantonalnym, rząd federalny ani parlament (składające się wyłącznie z mężczyzn) nie wykazywały inicjatywy w tej sprawie.

Światowy kryzys gospodarczy lat 1929-1939 jeszcze bardziej spowolnił proces dochodzenia praw wyborczych przez kobiety, które w owym

4 Switzerland's Long Way to Women's Right to Vote, History of Switzerland, http://history-switzerland.geschichte-schweiz.ch/chronology-womens-right-vote-switzerland.html, 13.04.2012.

5 Działało ono w ramach federacji grupującej lokalne stowarzyszenia szwajcarskich kobiet pracujących (SAV) w niemieckojęzycznej części kraju. Głównym celem organizacji była ochrona interesów pracowników-kobiet, które nie były reprezentowane przez związki zawodowe. Federacja została utworzona w 1890 r., a jej pierwszą przewodniczącą została Verena Conzett-Knecht; Conzett [-Knecht], Verena, 1.03.2005, Historisches Lexikon der Schweiz, http://www.hls-dhs-dss.ch/textes/d/ D9285.php, 14.04.2012.

6 Programm der Sozialdemokratischen Partei der Schweiz, 1904, http://www.sp-ps.ch/ger/Media-library/AA-SP-Schweiz/Partei/Parteiprogramme/Parteiprogramm-1904, 13.04.2012.

\footnotetext{
7 Switzerland's Long Way to Women's..., op. cit.
} 
czasie zostały „odesłane do kuchni”. Po drugiej wojnie światowej nastapił rodzaj politycznego przebudzenia i stare - przedwojenne - postulaty zaczęły być coraz bardziej słyszalne. Jednak nie zmieniło to dotychczasowego nastawienia Szwajcarów, którzy w kolejnych kantonalnych referendach zorganizowanych w latach 1946-1951 (w Bazylei, Genewie, Ticino, Zurychu, Neuchâtel, Solothurn i Vaud) wyrażali swój sprzeciw wobec praw wyborczych dla kobiet.

Jedną z pierwszych oznak pozytywnych zmian było kantonalne referendum w Bazylei-Mieście z 1957 r., mocą którego ustanowiono czynne prawo wyborcze dla kobiet na poziomie lokalnym - w trzech gminach ${ }^{8}$. Gmina Riehen jako pierwsza w Szwajcarii - 26 czerwca 1958 r. - przyznała paniom prawa wyborcze?

W roku 1958 parlament federalny po raz pierwszy głosował nad wprowadzeniem praw wyborczych dla kobiet na poziomie państwa. Propozycja została przyjęta w Radzie Narodowej głosami 96 do 42 oraz w Radzie Kantonów - 25 do 12 głosów.

W dniu 1 lutego 1959 r. odbyło się pierwsze ogólnonarodowe referendum $\mathrm{w}$ sprawie praw wyborczych dla kobiet ${ }^{10}$. Głosowanie zostało zakończone porażką zwolenników równouprawnienia - przy frekwencji $66,72 \% \%$ tylko 33,1\% (323 727 wyborców) poparło kobiety, a 66,9\% (654 939 wyborców) zagłosowało przeciw ${ }^{11}$.

Na poziomie kantonów - tylko trzy kantony: Vaud (51,3\% głosujących), Neuchâtel (52,2\% głosujących) i Genewa (60\% głosujących) poparły poddany pod głosowanie projekt. W niektórych małych kantonach w centrum kraju przeciwnicy wprowadzenia praw wyborczych dla kobiet stanowili nawet ponad 80\% (Uri, Schwyz, Obwalden, Nidwalden, Glarus). Podobna sytuacja pod względem poparcia była w kilku kantonach na wschodzie kraju (Turgowia, Sankt Gallen, Appenzell Ausserrhoden), a na szczególną uwagę zasługuje kanton Appenzell Inner-

8 A. Ladner, Switzerland: Subsidiary, power-sharing and direct democracy, w: The Oxford Handbook of Local and Regional Democracy in Europe, red. J. Loughlin, F. Hendriks, A. Lidström, Oxford 2011, s. 198.

9 E. Manz, Die Wegbereiterin aller Bundesrätinnen, 24.07.2010, „Tages Anzeiger", http://www.tagesanzeiger.ch/schweiz/standard/Die-Wegbereiterin-aller-Bundesraetinnen-/story/23894564, 15.04.2012.

10 G. A. Fossedal, Direct Democracy in Switzerland, New Brunswick-London 2009, s. 95.

11 Volksabstimmung vom 1. Februar 1959, Schweizerische Bundeskanzlei, http://www.admin.ch/ch/d//pore/va//19590201/index.html, 16.07.2012. 
rhoden, gdzie odnotowano 95\% głosów na „Nie”. Szczegółowe dane dotyczące poparcia $\mathrm{w}$ poszczególnych kantonach ${ }^{12}$ oraz w całym państwie przedstawiono $\mathrm{w}$ tabeli 1 .

Tabela 1

Wyniki referendum federalnego z dnia 1 lutego 1959 r. w sprawie przyznania kobietom praw wyborczych

\begin{tabular}{|c|c|c|c|c|c|c|c|}
\hline Kanton & $\begin{array}{c}\text { Upraw- } \\
\text { nieni } \\
\text { do głoso- } \\
\text { wania } \\
\end{array}$ & $\begin{array}{c}\text { Uczest- } \\
\text { niczący } \\
\text { w gloso- } \\
\text { waniu } \\
\end{array}$ & $\begin{array}{c}\text { Frek- } \\
\text { wencja } \\
(\%)\end{array}$ & TAK & TAK \% & NIE & NIE \% \\
\hline 1 & 2 & 3 & 4 & 5 & 6 & 7 & 8 \\
\hline Zurych & 260027 & 200537 & 77,12 & 71859 & 36,2 & 126670 & 63,8 \\
\hline Berno & 254582 & 158272 & 62,17 & 55786 & 35,5 & 101543 & 64,5 \\
\hline Lucerna & 69388 & 48480 & 69,87 & 10294 & 21,3 & 37934 & 78,7 \\
\hline Uri & 8717 & 6204 & 71,17 & 885 & 14,6 & 5183 & 85,4 \\
\hline Schwyz & 21136 & 13860 & 65,58 & 1968 & 14,2 & 11860 & 85,8 \\
\hline Obwalden & 6299 & 3946 & 62,64 & 565 & 14,3 & 3376 & 85,7 \\
\hline Nidwalden & 5809 & 4168 & 71,75 & 807 & 19,5 & 3331 & 80,5 \\
\hline Glarus & 10817 & 7652 & 70,74 & 1455 & 19,1 & 6159 & 80,9 \\
\hline Zug & 12997 & 8452 & 65,03 & 2046 & 24,3 & 6387 & 75,7 \\
\hline Fryburg & 45749 & 26866 & 58,72 & 7985 & 29,8 & 18780 & 70,2 \\
\hline Solothurn (Solura) & 55146 & 38732 & 70,24 & 11447 & 30,0 & 26692 & 70,0 \\
\hline Bazylea-Miasto & 67067 & 36451 & 54,35 & 17013 & 46,8 & 19372 & 53,2 \\
\hline Basel-Okręg & 38050 & 24025 & 63,14 & 8896 & 37,3 & 14969 & 62,7 \\
\hline $\begin{array}{l}\text { Schaffhausen } \\
\text { (Szafuza) }\end{array}$ & 17759 & 15385 & 86,63 & 4782 & 31,9 & 10212 & 68,1 \\
\hline Appenzell A.-Rh. & 13583 & 9963 & 73,35 & 1517 & 15,5 & 8284 & 84,5 \\
\hline Appenzell I.-Rh. & 3600 & 2171 & 60,31 & 105 & 4,9 & 2050 & 95,1 \\
\hline Sankt Gallen & 86796 & 65082 & 74,98 & 12436 & 19,3 & 51912 & 80,7 \\
\hline $\begin{array}{l}\text { Graubünden } \\
\text { (Gryzonia) }\end{array}$ & 37669 & 25549 & 67,83 & 5633 & 22,4 & 19562 & 77,6 \\
\hline
\end{tabular}

12 W zestawieniu brakuje kantonu Jura, który oficjalnie stał się kantonem Szwajcarii w 1979 r. Na Kongresie Wiedeńskim w 1815 r. Jura została przekazana kantonowi Berno, co stało się przyczyną wielu konfliktów w regionie. Wspomniane nieporozumienia wynikały z faktu, iż Jura była francuskojęzyczna i rzymsko-katolicka, natomiast Berno - niemieckojęzyczne i protestanckie. Po zakończeniu drugiej wojny światowej ruchy separatystyczne domagały się wyodrębnienia Jury od kantonu Berno. W 1979 r. Jura stała się pełnoprawnym członkiem Konfederacji Szwajcarskiej. 


\begin{tabular}{||r|r|r|r|r|r|r|c||}
\hline \multicolumn{1}{|c|}{1} & \multicolumn{1}{c|}{2} & \multicolumn{1}{c|}{3} & \multicolumn{1}{c|}{4} & \multicolumn{1}{c|}{5} & \multicolumn{1}{c|}{6} & \multicolumn{1}{c||}{} & 8 \\
\hline Aargau (Argowia) & 94208 & 79990 & 84,91 & 17919 & 22,8 & 60825 & 77,2 \\
\hline $\begin{array}{l}\text { Thurgau } \\
\text { (Turgowia) }\end{array}$ & 43478 & 34186 & 78,63 & 6721 & 19,9 & 26986 & 80,1 \\
\hline Tessin (Ticino) & 51396 & 29200 & 56,81 & 10738 & 37,1 & 18218 & 62,9 \\
\hline Waadt (Vaud) & 118485 & 64441 & 54,39 & 32929 & 51,3 & 31254 & 48,7 \\
\hline Wallis (Valais) & 48986 & 27155 & 55,43 & 8242 & 30,5 & 18759 & 69,5 \\
\hline $\begin{array}{l}\text { Neuenburg } \\
\text { Neuchâtel) }\end{array}$ & 41757 & 26897 & 64,41 & 13938 & 52,2 & 12775 & 47,8 \\
\hline Genewa & 67054 & 30179 & 45,01 & 17761 & 60,0 & 11846 & 40,0 \\
\hline Szwajcaria & $\mathbf{1 4 8 0 5 5 5}$ & $\mathbf{9 8 7} \mathbf{8 4 3}$ & $\mathbf{6 6 , 7 2}$ & $\mathbf{3 2 3} \mathbf{7 2 7}$ & $\mathbf{3 3 , 1}$ & $\mathbf{6 5 4} \mathbf{9 3 9}$ & $\mathbf{6 6 , 9}$ \\
\hline
\end{tabular}

Źrodło: Volksabstimmung vom 1. Februar 1959. Resultate in den Kantonen. Vorlage Nr. 191, Bundesbeschluss vom 13.06.1958 über die Einführung des Frauenstimm-und-wahlrechts in eidgenössischen Angelegenheiten, Schweizerische Bundeskanzlei, http://www.admin.ch/ch/ d//pore/va//19590201/can191.html, 15.06.2012.

Dodać warto, iż podczas kampanii przed referendum prawa wyborcze dla kobiet popierane były wyłącznie przez socjaldemokratów, związki zawodowe, małe niezależne partie polityczne i Partię Komunistyczną. Większość ugrupowań liberalnych i konserwatywnych pozostała niezdecydowana, natomiast partie z prawej strony sceny politycznej, a także niektóre wiejskie stowarzyszenia kobiet sprzeciwiały się proponowanemu pomysłowi.

Mimo przegranego referendum federalnego kanton Vaud przyznał kobietom prawo do głosowania na poziomie kantonalnym i lokalnym (1 lutego 1959 r.). Podobne decyzje podjęto w Neuchâtel (27 września 1959 r.) i w Genewie (6 marca 1960 r.) $)^{13}$.

Kolejnym kantonem, gdzie wprowadzono prawa wyborcze dla kobiet (w dniu 26 czerwca 1966 r.) była Bazylea-Miasto, będąca jednocześnie pierwszym niemieckojęzycznym kantonem, gdzie wprowadzono w życie tę zmianę. Dwa lata później tę samą decyzję podjęli wyborcy w kantonie Bazylea-Okręg.

Jeszcze przed drugim federalnym referendum w sprawie przyznania praw wyborczych kobietom dwa kantony zdołały przeforsować zmianę: 19 października 1969 r. - włoskojęzyczny kanton Ticino, 12 kwietnia 1970 r. Valais oraz 15 listopada 1970 r. - kanton Zurych.

13 A. Ladner, Switzerland:..., op. cit., s. 198. 
Drugie referendum, którego przedmiotem było przyznanie kobietom prawa głosowania w wyborach i referendach oraz prawa do kandydowania w wyborach, zostało przeprowadzone 7 lutego $1971 \mathrm{r}^{14}$, po tym jak $\mathrm{z}$ inicjatywy rządu propozycję tę przegłosował parlament federalny ${ }^{15}$.

I tak przy frekwencji 57,72\% (955 321 wyborców) nowa zmiana zdobyła poparcie 65,7\% (621 109 głosów) uczestniczących w głosowaniu. 34,3\% wyborców (323 882 głosów) sprzeciwiło się pomysłowi przyznania kobietom praw wyborczych. Szczegółowe dane dotyczące referendum przedstawiono $\mathrm{w}$ tabeli 2 .

Na poziomie kantonów inicjatywa wprowadzenia praw wyborczych dla kobiet spotkała się ze sprzeciwem ośmiu niemieckojęzycznych kantonów usytuowanych w centrum i na wschodzie kraju. Najmniejsze poparcie - podobnie jak w poprzednim referendum w tej kwestii - odnotowano w kantonach: Uri, Schwyz, Obwalden, Nidwalden, Glarus, Sankt Gallen, Turgowia, Appenzell Ausserrhoden i Appenzell Innerrhoden. Poparcie w tych regionach osiagnęło poziom od 28,9\% w Appenzel Innerhoden do 46,5\% i 46,7\% odpowiednio w Sankt Gallen i Obwalden.

Najwyższa poparcie w całej Szwajcarii odnotowano podobnie jak poprzednio - w kantonie Genewa - 91\%. Bardzo wielu zwolenników głosowany projekt wprowadzenia praw wyborczych dla kobiet zdobył również w trzech innych francuskojęzycznych kantonach: Vaud - 83,9\%, Neuchâtel - 82\% i Valais - 79,9\%. Poparcie na poziomie 82,2\% i 79,9\% odnotowano w kantonach Bazylea-Miasto i Bazylea-Okręg.

Warto w tym kontekście zauważyć, iż od momentu uchwalenia tzw. konstytucji założycielskiej - która weszła w życie 12 września 1848 r., przeobrażając dotychczasowy luźny związek kantonów w państwo federalne - do momentu przyznania kobietom praw wyborczych na szczeblu federacji minęły 123 lata.

Niezwykle interesująco przedstawia się porównanie poziomu poparcia dla rozpatrywanego projektu zmian w poszczególnych kantonach

14 T. S. Aidt, B. Dallal, Female voting power: the contribution of women's suffrage to the growth of social spending in Western Europe (1869-1960), „Public Choice" 2008, no 134, s. 391.

15 L. Langer, Panacea or Pathetic Fallacy? The Swiss Ban on Minarets, ,Vanderbilt Journal of Transnational Law" 2010, vol. 43; Bundesbeschluss über die Einführung des Frauenstimm- und Wahlrechts in eidgenössischen Angelegenheiten. Chronologie, Schweizerische Bundeskanzlei, http:/www.admin.ch/ch/d/pore/rf/cr/ 1970/19700220.html, 15,06.2012. 
Tabela 2

\section{Wyniki referendum federalnego z dnia 7 lutego 1971 r. w sprawie przyznania kobietom} praw wyborczych

\begin{tabular}{|c|c|c|c|c|c|c|c|}
\hline Kanton & $\begin{array}{c}\text { Upraw- } \\
\text { nieni } \\
\text { do głoso- } \\
\text { wania }\end{array}$ & $\begin{array}{c}\text { Uczest- } \\
\text { niczący } \\
\text { w głoso- } \\
\text { waniu }\end{array}$ & $\begin{array}{c}\text { Frek- } \\
\text { wencja } \\
(\%)\end{array}$ & TAK & TAK $\%$ & NIE & NIE \% \\
\hline Zurych & 290558 & 181136 & 62,34 & 119631 & 66,8 & 59375 & 33,2 \\
\hline Berno & 281027 & 144216 & 51,32 & 95466 & 66,5 & 48044 & 33,5 \\
\hline Lucerna & 78768 & 47343 & 60,10 & 29459 & 62,7 & 17512 & 37,3 \\
\hline Uri & 9671 & 6922 & 71,57 & 2477 & 36,3 & 4340 & 63,7 \\
\hline Schwyć & 24619 & 14158 & 57,51 & 5945 & 42,2 & 8136 & 57,8 \\
\hline Obwalden & 7057 & 3581 & 50,74 & 1668 & 46,7 & 1902 & 53,3 \\
\hline Nidwalden & 7190 & 4898 & 68,12 & 2703 & 55,8 & 2141 & 44,2 \\
\hline Glarus & 10403 & 6538 & 62,85 & 2692 & 41,3 & 3823 & 58,7 \\
\hline Zug & 17121 & 11349 & 66,29 & 6699 & 59,9 & 4483 & 40,1 \\
\hline Fryburg & 51384 & 27647 & 53,80 & 19404 & 71,1 & 7893 & 28,9 \\
\hline Solothurn (Solura) & 60309 & 35197 & 58,36 & 22030 & 64,1 & 12331 & 35,9 \\
\hline Bazylea-Miasto & 65572 & 33593 & 51,23 & 27480 & 82,2 & 5962 & 17,8 \\
\hline Basel-Okręg & 53118 & 26754 & 50,37 & 21229 & 79,9 & 5353 & 20,1 \\
\hline $\begin{array}{l}\text { Schaffhausen } \\
\text { (Szafuza) }\end{array}$ & 18875 & 15112 & 80,06 & 8252 & 56,7 & 6296 & 43,3 \\
\hline Appenzell A.-Rh. & 13496 & 8820 & 65,35 & 3485 & 39,9 & 5253 & 60,1 \\
\hline Appenzell I.-Rh. & 3803 & 1996 & 52,48 & 574 & 28,9 & 1411 & 71,1 \\
\hline Sankt Gallen & 97851 & 58933 & 60,23 & 27042 & 46,5 & 31114 & 53,5 \\
\hline \begin{tabular}{|l} 
Graubünden \\
(Gryzonia)
\end{tabular} & 42694 & 23594 & 55,26 & 12778 & 54,8 & 10524 & 45,2 \\
\hline Aargau (Argowia) & 109855 & 80102 & 72,92 & 39469 & 50,2 & 39229 & 49,8 \\
\hline $\begin{array}{l}\text { Thurgau } \\
\text { (Turgowia) }\end{array}$ & 45982 & 30941 & 67,29 & 13464 & 44,1 & 17046 & 55,9 \\
\hline Tessin (Ticino) & 57981 & 27511 & 47,45 & 20527 & 75,3 & 6719 & 24,7 \\
\hline Waadt (Vaud) & 130872 & 66767 & 51,02 & 55852 & 83,9 & 10696 & 16,1 \\
\hline Wallis (Valais) & 57794 & 30821 & 53,33 & 24442 & 79,9 & 6135 & 20,1 \\
\hline $\begin{array}{l}\text { Neuenburg } \\
\text { (Neuchâtel) }\end{array}$ & 43156 & 24773 & 57,40 & 20205 & 82,0 & 4426 & 18,0 \\
\hline Genewa & 75552 & 42619 & 56,41 & 38136 & 91,1 & 3738 & 8,9 \\
\hline Szwajcaria & 1654708 & 955321 & 57,73 & 621109 & 65,7 & 323882 & 34,3 \\
\hline
\end{tabular}

Źródło: Volksabstimmung vom 7. Februar 1971, Resultate in den Kantonen Vorlage Nr. 224, Bundesbeschluss vom 09.10.1970 über die Einführung des Frauenstimm- und Wahlrechts in eidgenössischen Angelegenheiten, http:/www.admin.ch/ch/d/pore/va/19710207/can224.html, 12.06.2012. 
w obu referendach - z 1959 i 1971 r. Jak widać na wykresie 1, we wszystkich kantonach odnotowano znaczący wzrost poziomu poparcia dla wprowadzenia praw wyborczych dla kobiet. W najbardziej „sceptycznych" kantonach ten wzrost był najmniejszy: w kantonach Uri, Glarus, Appenzell Ausserrhoden, Appenzell Innerhoden, Turgowia - na poziomie około $21-24 \%$. Nie zmienia to jednak faktu, iż poparcie dla projektu zmiany na przełomie kilkunastu lat pomiędzy obu głosowaniami federalnymi zwiększyło się ponad dwukrotnie. W Appenzell Innerrhoden inicjatywa zmian prawa na rzecz kobiet przekonała prawie sześciokrotnie więcej mężczyzn niż w przypadku głosowania z 1959 r. - poparcie wzrosło z $4,9 \%$ do $28,9 \%$.

Wykres 1. Poziom poparcia dla wprowadzenia praw wyborczych dla kobiet w referendach federalnych w 1959 r. i 1971 r. - poziom kantonów

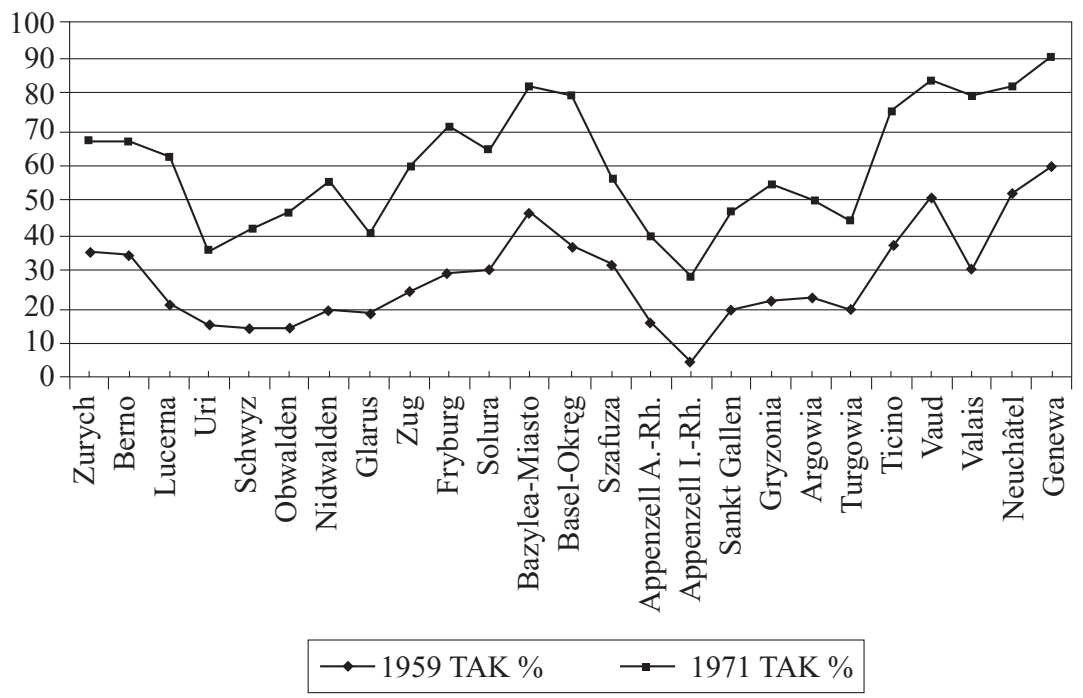

Źródło: Opracowanie własne na podstawie danych Schweizerische Bundeskanzlei.

Największy pod względem procentowym skok w poziomie poparcia odnotowano w pięciu kantonach: w Valais o 49,4\% (z 30,5\% do 79,9\%), w Bazylei-Okręgu o 42,6\% (z 37,3\% do 79,9\%), w Lucernie o 41,4\% (z $21,3 \%$ do $62,7 \%$ ), we Fryburgu o 41,3\% (z 29,8\% do 71,1\%) oraz we włoskim kantonie Ticino - o 38,2\% (z 37,1\% do 75,3\%).

Warto również zauważyć, że odwrotna tendencja odnotowana została w przypadku poziomu frekwencji wyborczej. W całej Szwajcarii zmniej- 
szyła się ona o około $9 \%$ - z $66,72 \%$ w pierwszym referendum do $57,79 \%$ w roku 1971. W zdecydowanej większości kantonów również odnotowano spadki, przy czym największe w Zurychu i w Sankt Gallen - odpowiednio o $14,78 \%$ (z $77,12 \%$ do $62,34 \%$ ) i o $14,75 \%$ (z $74,98 \%$ do $60,23 \%)$. Nieco mniejsze obniżenie frekwencji towarzyszyło głosowaniom w Bazylei-Okręgu o 12,77\% (z 63,14\% do 50,37\%) i Gryzonii o $12,57 \%$ (z $67,83 \%$ do 55,26\%). Podobnie w kantonach: Argowia - o $11,99 \%$ (z $84,91 \%$ do $72,92 \%$ ), Obwalden - o 11,9\% (z 62,64\% do $50,74 \%$ ), Solura - o $11,88 \%$ (z $70,24 \%$ do $58,36 \%$ ) i Turgowia - o 11,34 (z 78,63\% do 67,29\%).

Porównując dane dotyczące frekwencji w poszczególnych kantonach w obu referendach, zaznaczyć należy, iż tylko w trzech kantonach odnotowano wzrost poziomu partycypacji mężczyzn uprawnionych do głosowania: największy w kantonie Genewa, gdzie w obu referendach większość popierała przyznanie kobietom praw wyborczych - o 11,4\% (z 45,01\% do 56,41\%) i niewielkie wzrosty partycypacji w kantonach: Zug - o 1,26\% (z 65,03\% do 66,29\%) i Uri - o 0,4\% (z 71,17\% do 71,57\%).

Najważniejszym (ilościowym) efektem referendum było zwiększenie liczby osób uprawnionych do głosowania, jak i liczby osób, które dysponowały prawem do kandydowania w wyborach. Liczba ta została praktycznie podwojona - z 1654708 mężczyzn uprawnionych w referendum federalnym w lutym 1971 r. do liczby $3549426^{16}$ kobiet i mężczyzn w wyborach parlamentarnych 31 października $1971 \mathrm{r}$. W poprzednich wyborach parlamentarnych - w 1967 r. - liczba uprawnionych do głosowania wynosiła 1551909 mężczyzn $^{17}$. Należy również odnotować, iż w każdych kolejnych wyborach parlamentarnych po 1967 r. frekwencja wyborcza zmniejszyła się istotnie. W latach 1947-1967 partycypacja wyborcza wynosiła od $72 \% \mathrm{w}$ roku 1947 do $65,7 \% \mathrm{w}$ wyborach 20 lat później (przez 71,\% w 1951 r., 70,1\% w 1955 r., 68,5\% w 1959 r. i $66,1 \%$ w 1963 r. $)^{18}$. Zmniejszenie poziomu frekwencji wyborczej odnotowane w okresie 1967-1971 (o 8,8\%) było największym spadkiem udziału obywateli w wyborach parlamentarnych w latach 1922-2011.

16 Nationalratswahlen 1971-2011, Bundesamt für Statistik, http://www.bfs.ad$\mathrm{min} . \mathrm{ch} / \mathrm{bfs} /$ portal/de/index/themen/17/02/blank/key/national_rat/wahlbeteiligung.html, 15.05.2012.

17 Ibidem.

18 Ibidem. 


\section{Przyznanie kobietom praw wyborczych w szwajcarskich kantonach}

Jak zaznaczono powyżej, w pierwszych po referendum z 1971 r. wyborach parlamentarnych, które zostały przeprowadzone w październiku, prócz mężczyzn mogły również uczestniczyć - zarówno czynnie jak i biernie - kobiety. W przypadku każdego z kantonów czas przyjęcia ustanowionych na szczeblu federalnym zmian był zróżnicowany.

Wydaje się, że kierując się czasem wprowadzenia praw wyborczych dla kobiet, można podzielić szwajcarskie kantony na kilka grup.

Pierwszą są te regiony, które przyznały kobietom czynne i bierne prawa wyborcze w latach 1959-1960 - niejako „na fali” dyskusji wokół tego zagadnienia oraz pierwszego głosowania referendalnego w tej kwestii - jeszcze zanim uczyniono to na szczeblu federalnym (kantony Vaadt, Neuchâtel i Genewa). Następnie kilka kantonów - Bazylea-Miasto, Bazylea-Okręg, Ticino, Valais i Zurych - wprowadziło prawa wyborcze dla kobiet w latach 1966-1970 - jeszcze przed drugim federalnym referendum w tej sprawie. Do trzeciej grupy zaliczono dziewięć niemieckich kantonów, które implementowały zmianę prawa w roku 1971 r. - w krótkim czasie po referendum państwowym z lutego 1971 r. Dalej można wyróżnić kantony, gdzie kobiety uzyskały prawa wyborcze w roku kolejnym - 1972 (Sankt Gallen, Uri, Schwyz, Gryzonia, Nidwalden i Obwalden). Piątą grupę stanowią dwa niemieckojęzyczne półkantony Appenzell. Tam wprowadzenie praw wyborczych dla kobiet zajęło najwięcej czasu - 147 i 148 lat.

Wprowadzenie praw wyborczych dla kobiet w kantonach szwajcarskich ${ }^{19}$

\begin{tabular}{||l|l||}
\hline \multicolumn{1}{|c|}{ Data } & \multicolumn{1}{c|}{ Kanton } \\
\hline 1 & \multicolumn{1}{c||}{2} \\
\hline 1.02 .1959 & Vaud \\
\hline 27.09 .1959 & Neuchâtel \\
\hline 6.03 .1960 & Genewa \\
\hline 26.06 .1966 & Bazylea-Miasto \\
\hline
\end{tabular}

19 W zestawieniu nie ma kantonu Jura. W związku z tym, że został on oficjalnie włączony do Szwajcarii w 1979 r., a wcześniej był częścią Berna - prawa wyborcze kobiety miały tam od momentu włączenia tego kantonu do federacji (w wyniku przyznania kobietom praw wyborczych w Bernie w 1971 r.). 


\begin{tabular}{||l|l||}
\hline \multicolumn{1}{|c|}{1} & \multicolumn{1}{c|}{2} \\
\hline 23.06 .1968 & Bazylea-Okręg \\
\hline 19.10 .1969 & Ticino \\
\hline 12.04 .1970 & Valais \\
\hline 7.02 .11 .1970 & Zurych \\
\hline 2.05 .1971 & Argowia, Fryburg, Szafuza, Zug \\
\hline 6.06 .1971 & Glarus \\
\hline 25.10 .1971 & Solura \\
\hline 12.12 .1971 & Lucerna \\
\hline 23.01 .1972 & Berno, Turgowia \\
\hline 30.01 .1972 & Sankt Gallen \\
\hline 5.03 .1972 & Uri \\
\hline 30.04 .1972 & Schwyz i Gryzonia \\
\hline 24.09 .1972 & Nidwalden \\
\hline 30.04 .1989 & Obwalden \\
\hline 27.11 .1990 & Appenzell Ausserrhoden \\
\hline
\end{tabular}

Źródło: Opracowanie własne na podstawie materiałów zebranych w Schweizerische Bundeskanzlei oraz Switzerland's Long Way toWomen's Right to Vote, History of Switzerland, http://history-switzerland.geschichte-schweiz.ch/chronology-womens-right-vote-switzerland.html, 12.06.2012.

Szczegółowe dane dotyczące wprowadzenia praw wybiorczych dla kobiet w poszczególnych kantonach zawarte zostały w tabeli 3.

Jeśli chodzi o Appenzell, to podczas gdy większość kantonów rozszerzyła prawa wyborcze na kobiety praktycznie do 1972 r., te dwa konserwatywne półkantony we wschodniej Szwajcarii odmawiały wprowadzenia zmian. Jednym $\mathrm{z}$ argumentów podawanych w literaturze specjalistycznej jest wartość, jaka przypisywana jest w Appenzell - lokalnej autonomii. Przypomnieć bowiem należy, iż oba półkantony są odizolowane pod względem geograficznym: leżą w górach i z każdej strony są otoczone kantonem Glarus. Analizując mapę Szwajcarii możne odnieść wrażenie, że wchodzą one w skład kantonu Glarus. Tym, co odróżnia i jednocześnie izoluje oba Appenzell jest - jak zaznacza Lee Ann Banaszak - ich dialekt i tradycja. Elementy te jeszcze bardziej wzmacniają poczucie lokalnej autonomii wśród mieszkańców obu regionów. Dodać warto, że wielu działaczy na rzecz praw wyborczych twierdziło, iż obywatele obu Appenzell są nieufni wobec obcych i czują się urażeni, gdy są zmuszani 
do zaakceptowania i przyjęcia idei, pomysłów narzucanych przez rząd federalny. Jeszcze inni aktywiści - według Banaszak - sygnalizowali istnienie pewnego zjawiska, polegającego na tym, iż mężczyźni z Appenzell poczuli się $\mathrm{w}$ tym przypadku jakby ich autonomia była zagrożona przez ingerencję $\mathrm{z}$ zewnątrz ${ }^{20}$.

Warto zauważyć, iż w latach osiemdziesiątych XX stulecia zwiększyła się znacznie presja opinii publicznej względem obu kantonów w tej kwestii. Dodatkowo, za każdym razem kiedy w obu kantonach organizowane było coroczne zgromadzenie ludowe - Landsgemeinde - i pojawiał się tam temat praw wyborczych - przedstawiciele mediów zarówno tych szwajcarskich, jak i zagranicznych licznie przyjeżdżali, by śledzić sprawę przyznania praw wyborczych kobietom. Ich relacje pokazywały, jak zacofane i unikalne są oba kantony szwajcarskie w porównaniu do reszty Europy. Taka sytuacja jeszcze bardziej potegowała poczucie autonomii i izolacji wśród mieszkańców Appenzell ${ }^{21}$.

W związku ze wspomnianą powyżej presją - szczególnie ze strony szwajcarskiej opinii publicznej - mężczyźni z Appenzell Ausserrhoden postanowili jednak poddać pod głosowanie przyznanie kobietom czynnych i biernych praw wyborczych na poziomie kantonu. Projekt został zaakceptowany podczas Landgemeinde w dniu 30 kwietnia 1989 r.

Ostatnim kantonem, w którym umożliwiono kobietom uczestniczenie w życiu politycznym, był kanton Appenzell Innerhoden. W tym kantonie decyzja nie została podjęta podczas corocznego zgromadzenia ludowego przez wyborców, ale była konsekwencją orzeczenia Trybunału Federalnego. Orzeczenie było wynikiem sporu wokół interpretacji słowa „obywatel” w konstytucji federalnej. Konstytucja z 1948 r. (zresztą ta z 1798 r. również) nie określała tego, kto jest obywatelem Szwajcarii - czy tylko mężczyźni, czy może również mogą w tę grupę zostać włączone kobiety. Przez długi okres czasu uważano, że wyjaśnienie tej kwestii winno być uczynione wyłącznie w drodze referendum. Jednak po tym, jak mężczyźni z Appenzell Innerrhoden ogłosili, że i tak nie przyjmą zmiany długotrwałej „tradycji”, kobiety skierowały sprawę do rozstrzygnięcia do sądu. Trybunał 27 listopada 1990 r. orzekł, że przyznanie kobietom praw wyborczych w Appenzell Innerrhoden nie wymaga zmiany konstytucji kantonalnej. Skład sędziowski dodał, iż jego

20 L. A. Banaszak, Why Movements Succeed Or Fail: Opportunity, Culture, and the Struggle for Woman Suffrage, Princeton-New Jersey 1996, s. 210-211.

21 Ibidem, s. 212. 
stanowisko jest wystarczające, aby interpretować istniejącą konstytucję w taki sposób, że kobiety i mężczyźni są obywatelami państwa ${ }^{22}$.

\section{Podsumowanie}

Jednym $\mathrm{z}$ interesujących aspektów rozwoju systemu politycznego współczesnych państw jest proces uzyskiwania praw politycznych, wyborczych przez kobiety. Szwajcaria - ze względu na swoje wyjątkowe rozwiązania instytucjonalne oraz na swoją opinię jako państwa uznawanego za „perłę demokracji” - wydaje się być w tym kontekście niezmiernie interesującym (jak i zaskakującym) przykładem. Przypomnieć należy, iż Szwajcaria - jeśli chodzi o prawa wyborcze kobiet - została wyprzedzona przez takie państwa jak Egipt (1956), Kolumbia (1957), Irak (1958), Tanzania (1958), Nepal (1959), Rwanda (1961), Somalia (1961), Mozambik (1963), Burundi (1965) czy Lesoto (1966) ${ }^{23}$.

Kobiety w Szwajcarii niewątpliwie przeszły długą drogę w walce o prawa wyborcze nie tylko na szczeblu federacji, ale także - a może przede wszystkim - na poziomie kantonów. Szukając przyczyn tak późnego wprowadzenia praw wyborczych dla kobiet wydaje się, że przykład szwajcarski zbliżony jest do przypadku Liechtensteinu ${ }^{24}$. Oba państwa pozostawały niejako na uboczu istotnych wydarzeń europejskich czy światowych, co też mogło przełożyć się na znaczne opóźnienie w tym zakresie w porównaniu do innych krajów europejskich. Zauważyć należy, iż Księstwo Liechtensteinu wprowadziło prawa wyborcze w $1984 \mathrm{r}$. - 5 i 6 lat wcześniej od obu kantonów Appenzell ${ }^{25}$.

22 P. Funk, Ch. Gathmann, What women want: Suffrage, female voter preferences and the scope of government, 2005, s. 18, http://www.eea-esem.com/files/papers/EEA-ESEM/2006/337/Women_Suffrage.pdf, 12.06.2012; Switzerland's Long Way..., op. cit.; Women's long march to political parity, The Swiss Portal, http://www.ch.ch/private/00987/01052/01054/02321/index.html?lang=en, 12.06.2012.

23 Chronology of Worldwide Woman Suffrage, International Museum of Women, http://www.imow.org/dynamic/press_pdfs/press_pdfs_pdf_144.pdf, 12.06.2012.

24 Szerzej o prawach wyborczych kobiet w Lichtensteinie w tekście: K. Koźbiał, Prawa wyborcze kobiet $w$ Lichtensteinie, w: Kobiety we współczesnym świecie. Rola $i$ miejsce kobiet $w \dot{z} y c i u$ politycznym, red. M. Musiał-Karg, B. Secler, Poznań 2010, s. $55-76$.

25 Ibidem. 
Jednak najważniejszym z powodów tak długiego procesu wprowadzania praw wyborczych dla kobiet wydają się być funkcjonujące w Szwajcarii mechanizmy demokracji bezpośredniej. Instytucje demokracji bezpośredniej z jednej strony umożliwiają wprowadzanie zmian w państwie, w kantonach, w gminach po ich uprzednim zaakceptowaniu przez wyborców, z drugiej natomiast - czego przykładem jest analizowana w tekście kwestia praw wyborczych kobiet - spowalniają wprowadzanie zmian politycznych. Krytycy demokracji bezpośredniej, zwracają w związku z powyższym uwagę, że bezpośrednie formy rządzenia są powolne i uciążliwe - przede wszystkim dla instytucji politycznych: parlamentu czy rządu. Przygotowywane bowiem przez polityków projekty zmian mogą być odrzucane przez społeczeństwo, co powoduje, że może upłynąć nawet kilka lub kilkanaście lat zanim jakiś projekt wejdzie w życie. Jeśli do tego doda się konieczność uzyskania tzw. „podwójnej większości" (wyborców i kantonów), wówczas dany projekt zmiany konstytucji może być jeszcze bardziej oddalony w czasie. Zaznaczyć warto, iż według niektórych badaczy, „podwójna większość” niesprawiedliwie stawia mniejsze (i bardziej konserwatywne) kantony w lepszej sytuacji w stosunku do reszty regionów.

Gdy z kolei jeszcze doda się proces wdrażania decyzji federalnej na szczeblu kantonów - okres przyjęcia nowego prawa we wszystkich regionach jest jeszcze bardziej wydłużony. Przykładem tego stanu rzeczy jest niewątpliwie proces przyznawania kobietom praw wyborczych w Szwajcarii. W roku 1959 pomimo akceptacji parlamentu, nie wystarczyło głosów wyborców i większości kantonów, by zmianę wprowadzić w życie. Pomimo iż nowelizacja prawa została przyjęta w wyniku referendum w 1971 r., cześć kantonów zwlekała z wdrożeniem jej przez kilka lub kilkanaście lat. To spowodowało, że Szwajcarki stały się jednymi z ostatnich kobiet w Europie, które mogły uczestniczyć w państwowych głosowaniach powszechnych oraz w referendach i wyborach na niższym szczeblu podziału administracyjnego państwa.

\section{Bibliografia}

Aidt T. S., Dallal B., Female voting power: the contribution of women's suffrage to the growth of social spending in Western Europe (1869-1960), „Public Choice” 2008, no 134.

Banaszak L. A., Why Movements Succeed Or Fail: Opportunity, Culture, and the Struggle for Woman Suffrage, Princeton-New Jersey 1996. 
Bundesbeschluss über die Einführung des Frauenstimm- und Wahlrechts in eidgenössischen Angelegenheiten. Chronologie, Schweizerische Bundeskanzlei, http://www.admin.ch/ch/d/pore/rf/cr/1970/19700220.html.

Chronology of Worldwide Woman Suffrage, International Museum of Women, http://www.imow.org/dynamic/press_pdfs/press_pdfs_pdf_144.pdf.

Conzett [-Knecht], Verena, 1.03.2005, Historisches Lexikon der Schweiz, http://www.hls-dhs-dss.ch/textes/d/D9285.php.

Fossedal G. A., Direct Democracy in Switzerland, New Brunswick-London 2009, s. 95.

Funk P., Gathmann Ch., What women want: Suffrage, female voter preferences and the scope of government, 2005, http://www.eea-esem.com/files/papers/EEA-ESEM/ 2006/337/Women_Suffrage.pdf.

Koźbiał K., Prawa wyborcze kobiet w Lichtensteinie, w: Kobiety we wspótczesnym świecie. Rola i miejsce kobiet $w$ życiu politycznym, red. M. Musiał-Karg, B. Secler, Poznań 2010.

Kobiety we wspótczesnym świecie. Rola i miejsce kobiet w życiu politycznym, red. M. Musiał-Karg, B. Secler, Poznań 2010.

Ladner A., Size and direct democracy at the local level: the case of Switzerland, „Environment and Planning. Government and Policy” 2000, vol. 20.

Ladner A., Switzerland: Subsidiary, power-sharing and direct democracy, w: The Oxford Handbook of Local and Regional Democracy in Europe, red. J. Loughlin, F. Hendriks, A. Lidström, Oxford 2011.

Langer L., Panacea or Pathetic Fallacy? The Swiss Ban on Minarets, „Vanderbilt Journal of Transnational Law" 2010, vol. 43.

Linder W., Blaski i cienie demokracji bezpośredniej, w: Demokracja bezpośrednia. Szwajcarska demokracja modelem dla XXI wieku?, red. K. Koźbiał, Warszawa 2011.

Manz E., Die Wegbereiterin aller Bundesrätinnen, 24.07.2010, „Tages Anzeiger”, http://www.tagesanzeiger.ch/schweiz/standard/Die-Wegbereiterin-aller-Bundesraetinnen-/story/23894564.

Nationalratswahlen 1971-2011, Bundesamt für Statistik, http://www.bfs.admin.ch/ bfs/portal/de/index/themen/17/02/blank/key/national_rat/wahlbeteiligung.html.

Programm der Sozialdemokratischen Partei der Schweiz, 1904, http://www.sp-ps.ch/ger/ Media-library/AA-SP-Schweiz/Partei/Parteiprogramme/Parteiprogramm-1904.

Switzerland's Long Way to Women's Right to Vote, History of Switzerland, http://history-switzerland.geschichte-schweiz.ch/chronology-womens-right-vote-switzerland.html.

Women's long march to political parity, The Swiss Portal, http://www.ch.ch/private/00987/01052/01054/02321/index.html?lang=en.

Volksabstimmung vom 1. Februar 1959, Schweizerische Bundeskanzlei, http://www.ad$\mathrm{min} . \mathrm{ch} / \mathrm{ch} / \mathrm{d} / /$ pore/va//19590201/index.html. 
Volksabstimmung vom 7. Februar 1971, Resultate in den Kantonen Vorlage Nr. 224, Bundesbeschluss vom 09.10.1970 über die Einführung des Frauenstimm- und Wahlrechts in eidgenössischen Angelegenheiten, http://www.admin.ch/ch/ d/pore/va/19710207/can224.html.

\title{
Direct democracy and the granting of women's suffrage as illustrated by Switzerland
}

\begin{abstract}
Summary
Over the centuries, Switzerland has developed a unique and inimitable statehood that functions in peculiar geographical, social and political conditions, shaped by the tradition of exercising direct forms of power. It appears, however, that these tools of direct democracy can sometimes obstruct the changes of utmost significance for the development of modern statehood and democracy. This was the case of granting voting rights to women. Although many European and other states granted the rights to vote and stand for election to women in the 1920s and 1930s, Switzerland needed much longer to introduce this change: on the federal level, women's suffrage was granted as late as in 1971, and the last to enjoy the right to partake in the political life of their canton were the women of Appenzell Innerrhoden, granted the right in 1990. The objective of this paper is to analyze the influence of the mechanisms of direct democracy on the introduction of voting rights for Swiss women.
\end{abstract}


